\title{
RESPONSE OF ESTUARINE MEIOFAUNA ASSEMBLAGE TO EFFECTS OF FERTILIZER ENRICHMENT USED IN THE SUGAR CANE MONOCULTURE. PERNAMBUCO, BRAZIL
}

Paulo J. P. Santos ${ }^{1 *}$; Mônica L. Botter-Carvalho ${ }^{I}$; Ananias B. do Nascimento-Júnior ${ }^{\prime}$; Raquel G. C. Marinho ${ }^{\prime}$, Paulo V. V. C. Carvalho ${ }^{2}$ and Ana P. M. C. Valença'.

${ }^{1}$ Universidade Federal de Pernambuco

(Av. Prof. Moraes Rêgo s/n, Cidade Universitária, 50640-920 Recife, PE, Brasil)

${ }^{2}$ Companhia Pernambucana de Saneamento

(Praça Dois Irmãos, 1012, 52071-440 Recife, PE, Brasil)

*Corresponding author: pjps@ufpe.br

\begin{abstract}
A B S T R A C T
In situ application of inorganic fertilizer was used to simulate environmental eutrophication associated with the sugar cane monoculture. Meiofauna community structure is herein used to assess this experimental impact. Nine quadrangular areas $\left(4 \mathrm{~m}^{2}\right.$ each) were randomly defined in the midlittoral estuarine area. Three of these areas received a high dose of sugar cane fertilizer $\left(375 \mathrm{~g} / \mathrm{m}^{2}\right.$ Nitrogen-Phosphorus-Potassium), three areas received a low dose of the fertilizer $\left(187.5 \mathrm{~g} / \mathrm{m}^{2}\right)$ and the other three areas represented the control. The fertilizer was applied every week. Environmental parameters and meiofauna were sampled using three-to-four week intervals. Six samplings were subsequently performed maintaining this interval. Meiofauna was counted and identified to major taxonomic groups. Meiofauna community structure varied throughout the experimental areas. Control areas maintained their abundance values during the study period, but within the enriched areas meiofauna abundance decreased greatly. MDS and ANOSIM analysis showed significant variation in the meiofauna community structure among experimental areas and also along the experimental period in the enriched areas.
\end{abstract}

\section{R ESUMO}

A aplicação in situ de fertilizantes inorgânicos foi utilizada para simular a eutrofização associada ao cultivo da cana-de-açúcar. A estrutura da associação de meiofauna foi analisada com o objetivo de avaliar este impacto. O experimento de enriquecimento do sedimento foi desenvolvido em nove áreas quadrangulares de $4 \mathrm{~m}^{2}$ distribuídas de forma aleatória no mediolitoral da área estuarina. Três áreas foram enriquecidas com alta concentração $\left(375 \mathrm{~g} / \mathrm{m}^{2}\right)$ de NPK (Nitrogênio-Fósforo-Potássio), três com baixa concentração $\left(187,5 \mathrm{~g} / \mathrm{m}^{2}\right)$ e as demais tratadas como controle. Os fertilizantes foram aplicados semanalmente. Os parâmetros físico-químicos do sedimento e a meiofauna bentônica foram coletados após três a quatro semanas da aplicação dos fertilizantes. Obedecendo este intervalo foram realizadas 6 amostragens subseqüentes. As amostras foram triadas e a meiofauna contada e identificada em nível de grande grupo. As respostas da meiofauna variaram de acordo com a área: enquanto a área Controle manteve sua abundância total durante todo o experimento, as áreas tratadas apresentaram forte queda nas densidades totais. A ordenação MDS e a análise ANOSIM evidenciaram mudanças significativas na estrutura da associação de meiofauna entre as áreas e também ao longo do experimento nas áreas tratadas.

Descriptors: Estuarine Meiobenthos, Eutrophication, Sugar cane, In situ experiment Descritores: Meiobentos estuarino, Eutrofização, Cana-de-açúcar, Experimento in situ

\section{INTRODUCTION}

The major external sources of the nutrients and dissolved and particulate organic matter in coastal waters are domestic sewage and agricultural fertilizer input (see GRAY et al. (2002) and references therein).

In the semi-arid zone of Northeastern Brazil, sugar cane is a significant agricultural and industrial factor due to the historical development of the region, as well as to the introduction of the Brazilian bioalcohol program (GUNKEL et al., 2006). Covering a significant part $(40.1 \%)$ of the northern coast of the State of Pernambuco, sugar cane cultivation is the predominant soil use in the hinterland of several cities (CPRH, 2001). In Northeastern Brazil the demand for $\mathrm{N}$ fertilization is particularly high for sugar cane (90 to 
$275 \mathrm{~kg} \cdot \mathrm{ha}^{-1}$ ) and much greater $\mathrm{N}$ and $\mathrm{P}$ losses are due to this activity ( $26-32 \%$ for $\mathrm{N}$ and $6-20 \%$ for $\mathrm{P}$ ) than to any other. According to a study of 16 estuaries on the Northeast Brazilian coast, agriculture was responsible for $25 \%$ and $31 \%$, respectively, of anthropogenic $\mathrm{N}$ and $\mathrm{P}$ input to estuarine waters, the contribution from natural sources being negligible (LACERDA et al., 2008).

Eutrophication arises from an increase in nutrient and dissolved organic matter concentrations above natural levels, which in turn leads to a greater production of particulate organic matter. The amounts of organic matter produced are often too large to be consumed and sink to the seabed along with faeces and other particulate organic matter. The sedimenting organic matter is degraded largely in the water column, a process that takes up oxygen. If oxygen is not supplied by advective and vertical mixing then decreases in oxygen concentrations lead to hypoxia and, in extreme cases, to anoxia (GRAY et al., 2002), causing severe consequences within the benthic system, including the meiofauna (HEIP, 1995).

Meiofauna is widely abundant in estuarine sediments and was first defined as the aquatic metazoan group retained by sieves of between 0.045 and $0.5 \mathrm{~mm}$ mesh (MARE, 1942). Nowadays the term is most frequently used as a synonym of meiobentos to include also the unicellular fauna (GIERE, 1993). The different meiofauna groups have recently been recognized as important components of the benthic system since they facilitate the biomineralization of organic matter, may be used as food by higher trophic levels and show great sensitivity to anthropogenic impacts (COULL, 1999). In addition to natural variables, anthropogenic impacts including eutrophication, pollution and physical disturbances exert a substantial influence on the meiofauna, especially in coastal areas (STEYAERT et al., 1999). According to Kennedy and Jacoby (1999), meiofauna organisms are shown to have advantages as biological indicators due to their sessile habit, high species diversity, short generation time, direct benthic development and ubiquitous distribution. Disadvantages include their small size, high level of spatial and temporal variability, the potential cost of sample processing and the limited taxonomic literature accessible to non-specialist workers.

The aim of this study is to ascertain the response of the estuarine meiofauna assemblage to in situ applications of the main inorganic fertilizers used in the sugar cane monoculture.

\section{Study Area}

The study area is part of the coastal estuarine complex of the Itamaracá Island $\left(7^{\circ} 46,184^{\prime} \mathrm{S}\right.$ and $34^{\circ} 52,926^{\prime} \mathrm{W}$ ) on the north coast of Pernambuco State (Brazil), about $50 \mathrm{~km}$ from the city of Recife (Fig. 1). The island is separated from the continent by the Santa Cruz Channel, connected to the Atlantic Ocean by the Catuama Bar in the north and the Orange Bar in the south. The Santa Cruz Channel estuarine complex is characterized by extensive highly productive mangrove areas with great biodiversity. As with most estuaries, the Itamaracá ecosystem is exposed to multiple pressures from industrial pollution, domestic sewage discharge, urban expansion, land reclamation and fisheries (SILVA et al. 2003), the sugar-cane monoculture constituting the basis of various municipalities' economies (CPRH, 2001).
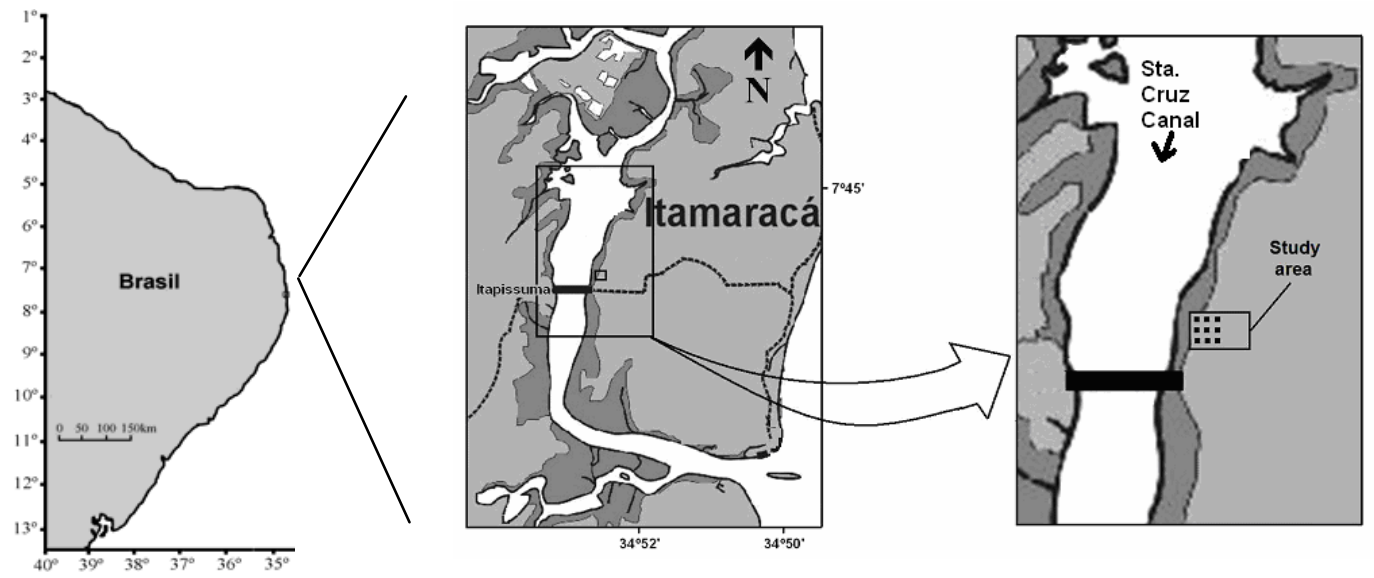

Fig.1. Localization of the Itamaracá Island and Santa Cruz Canal for study area location and arrangement of the experimental areas (modified from Botter-Carvalho, 2007). 


\section{Material and Methods}

Experimental work and samplings were carried out between October 2005 and January 2006. The experiment was performed within nine quadrangular areas of $4 \mathrm{~m}^{2}$ each (replicates), $3 \mathrm{~m}$ equidistant, six areas being enriched weekly with the most commonly used inorganic fertilizer in the sugar cane monoculture of Pernambuco: the NPK TREVO $\left(\right.$ YARA $^{\mathbb{B}}$ ). Thus, three of these areas received the Low Dose - LD $\left(750 \mathrm{~g} / 4 \mathrm{~m}^{2}\right)$ of fertilizer while the other three received the High dose - HD $\left(1500 \mathrm{~g} / 4 \mathrm{~m}^{2}\right)$. The three remaining areas were maintained in natural condition as Controls - C. Nitrogen and Phosphorous dosages applied in the fertilization were calculated from mean values of total- $\mathrm{N}$ and total-P previously measured in the environment.

Sampling days occurred according to the following frequency, which varied as a function of the tides appropriate for sampling, from October $5^{\text {th }}, 2005$ : Day $0(10 / 05 / 2005)$, first NPK application; Day 26 $(10 / 31 / 2005), \quad$ Day 43 (11/17/2005), Day 71 $(12 / 15 / 2005)$, Day 91 (01/04/2006), Day 118 $(01 / 31 / 2006)$. Sampling points for each area (HD, LD and $\mathrm{C}$ ) were previously randomly determined. All sediment samples were stratified at two depths (strata): $0-2 \mathrm{~cm}$ and $2-5 \mathrm{~cm}$

Three replicates were sampled in each area (High Dose, Low Dose and Control) and three pseudoreplicates were sampled in each area for the following environmental variables: microphytobenthic chlorophyll-a and phaeopigments (corer area 1.13 $\mathrm{cm}^{2}$ ), and organic matter (corer area $16.62 \mathrm{~cm}^{2}$ ). A single replicate was sampled in each area for meiofauna (corer area $6.15 \mathrm{~cm}^{2}$ ) and inorganic nutrient (corer area $16.62 \mathrm{~cm}^{2}$ ) analyses (total-nitrogen and total-phosphorous) thus totalizing three units for each treatment. A single replicate (corer area $16.62 \mathrm{~cm}^{2}$ ) was also sampled in each area for sediment composition (percentage of silt+clay) but this parameter was analyzed only for the initial (Day 0) and final (Day 118) samplings.

Sediment redox potential (Eh) was measured in situ using a platinum electrode inserted deeply into the central point of each stratum.

Microphytobenthic biomass was expressed as chlorophyll- $a$ concentration per unit of area $(\mu \mathrm{g} . \mathrm{cm}$ ${ }^{2}$ ). Chlorophyll-a and phaeopigment concentrations were determined by spectrophotometry in accordance with Colijn and Dijkema, (1981) and calculated on the basis of Lorenzen's equations (1967).

Sedimentary organic matter (\%) was calculated according to the modified method of Wetzel and Likens (1990). Sedimentary Total Nitrogen was determined by Kjeldahl's method and Total
Phosphorus by the Mhelich method, both following the procedure proposed by EMBRAPA (1997).

After staining with Rose Bengal, biological samples were passed through a $0.5 \mathrm{~mm}$ mesh and the animals retained on a $0.063 \mathrm{~mm}$ sieve were fixed in 4\% Formalin (HIGGINS; THIEL, 1988). Sorting and counting were performed under the stereomicroscope and taxa were identified to the major taxonomic group level.

Spatio-temporal differences in meiobenthic community structure were evaluated using density and relative abundance of major groups and multivariate analyses. The Multidimensional scaling analysis (MDS) was used to verify spatial differences among areas (Control, Low Dose and High dose), days and strata. Analyses of Similarity - ANOSIM - (CLARKE, 1993) were performed to test the significance of experimental cluster configuration and detect eventual time gradients. Relations between multivariate components of community structure and environmental variables were assessed using the BIOENV routine (CLARKE; AINSWORTH, 1993). Statistical analyses were applied according to Clarke and Warwick (1994).

\section{RESULTS}

The sedimentary percentage of silt-clay was similar among treatments, with an average value for all samples of $28.8 \%$ (Fig. 2).

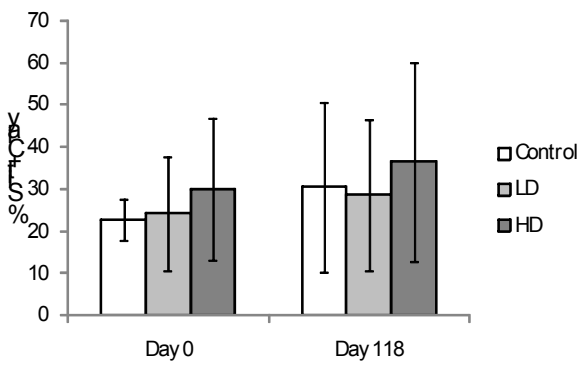

Fig. 2. Sediment silt and clay percentage at Control, Low Dose and High Dose areas on days 0 and 118. Bars define $95 \%$ confidence intervals.

The sediment presented strongly reduced conditions throughout the experiment. Redox potential (Eh) always presented negative values. Results obtained for each stratum showed more greatly reduced conditions in the second stratum $(2-5 \mathrm{~cm})$. The $\mathrm{HD}$ area presented more negative Eh values in both strata with a gradual increase in the reduced conditions up to Day 118 (final experiment) (Fig. 3). 
$0-2 \mathrm{~cm} \mathrm{~A}$
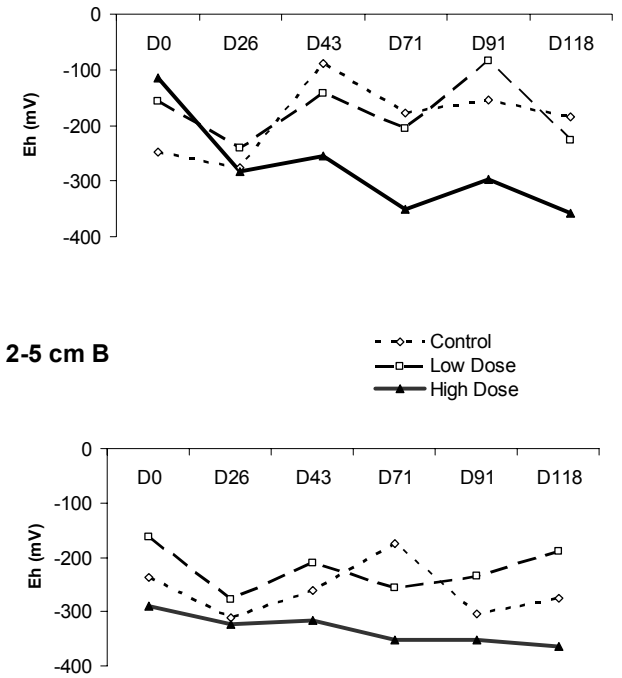

Fig. 3. Redox potential (Eh) in the $0-2 \mathrm{~cm}(\mathrm{~A})$ and $2-5 \mathrm{~cm}$ (B) strata - Control, Low Dose and High Dose areas.

After one week of fertilizer application, the LD areas presented a strong yellow-green color (mainly diatoms) and the HD sediments already showed a blue-green color (mainly cyanobacteria) (ML Botter-Carvalho and PVVC Carvalho, personal observations). In the control areas, algal patches presented a clear brown color during the study period. After three fertilizer applications (Day 26 sampling) some HD areas already demonstrated signs of decomposition with dark green coloration and gas bubbles.

Chlorophyll-a concentration presented higher values at the surface $(0-2 \mathrm{~cm})$ though with small variations across sampling days. An increment in the chlorophyll-a and phaeopigment concentrations in the fertilized areas was observed on Day 91, especially in the HD areas and in the $0-2 \mathrm{~cm}$ stratum (Fig. 4) but without significant differences. Phaeopigment concentrations were slightly lower at the surface $(0-2 \mathrm{~cm})$ than in the deeper $(2-5 \mathrm{~cm})$ stratum (Fig. 5).

No significant differences were observed among sampling days or strata $(0-2 \mathrm{~cm}$ and $2-5)$ for organic matter. Confidence intervals were invariably higher in the HD area (Fig. 6).

Total-N concentrations were similar for both strata and throughout the duration of the experiment. The HD area presented greater heterogeneity with large standard deviations (Fig. 7).

\section{$0-2 \mathrm{~cm} \mathrm{~A}$}
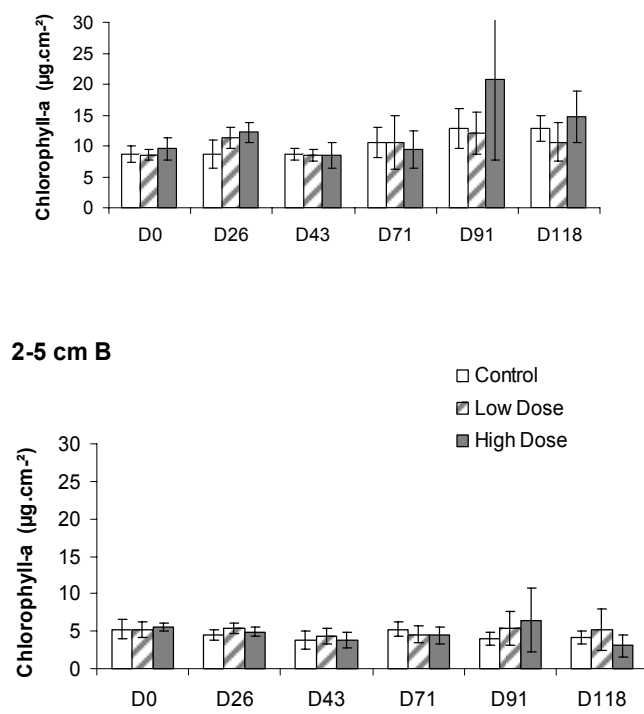

Fig. 4. Chlorophyll-a concentrations in the 0-2 cm (A) and 2$5 \mathrm{~cm}$ (B) strata - Control, Low Dose and High Dose areas. Bars define $95 \%$ confidence intervals.

\section{$0-2 \mathrm{~cm} \mathrm{~A}$}
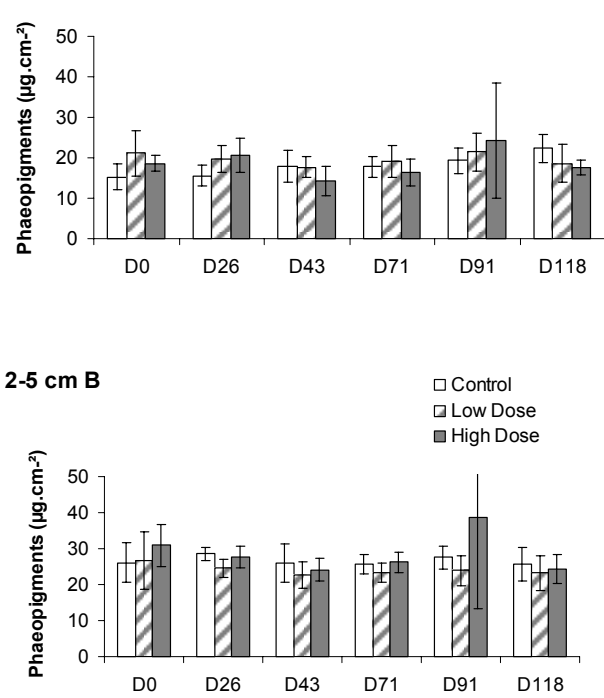

Fig. 5. Phaeopigments concentrations in the $0-2 \mathrm{~cm}(\mathrm{~A})$ and 2-5 cm (B) strata - Control, Low Dose and High Dose areas. Bars define $95 \%$ confidence intervals. 

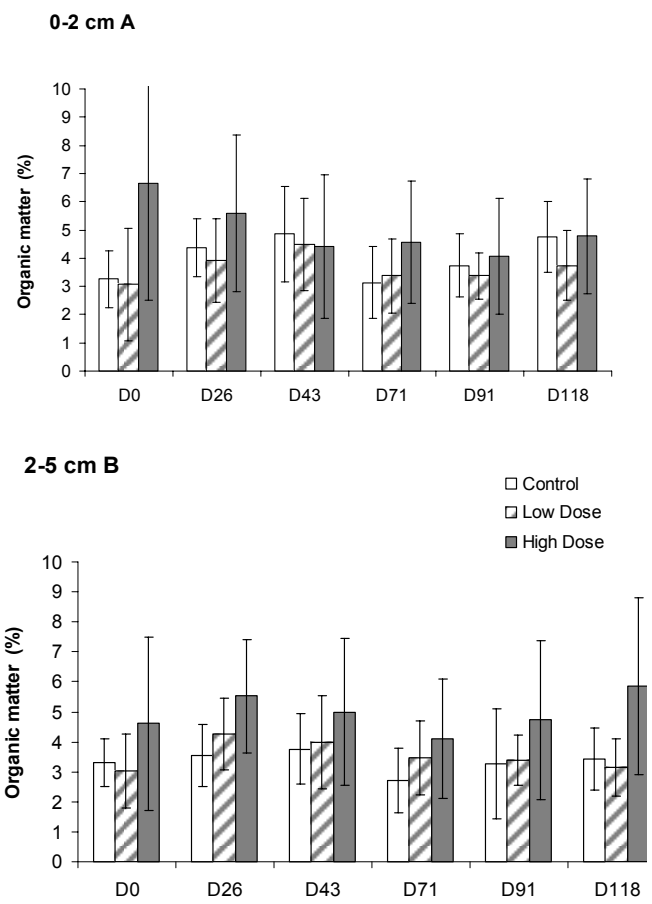

Fig. 6. Organic matter in the $0-2 \mathrm{~cm}(\mathrm{~A})$ and $2-5 \mathrm{~cm}(\mathrm{~B})$ strata - Control, Low Dose and High Dose areas. Bars define 95\% confidence intervals.

\section{$0-2 \mathrm{~cm} \mathrm{~A}$}
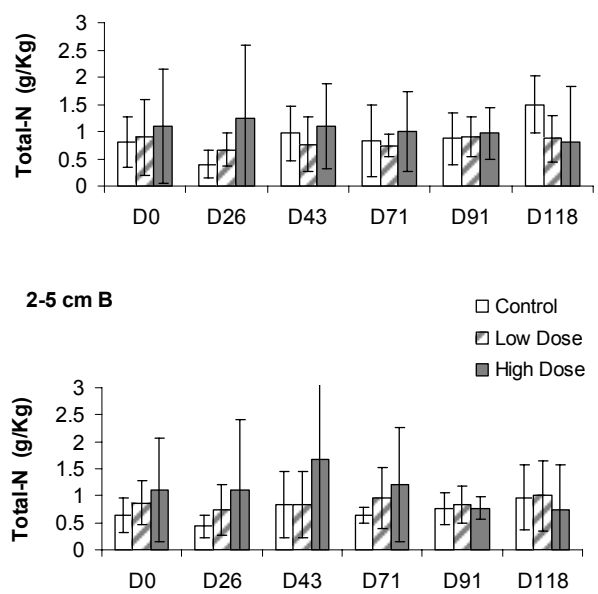

Fig. 7. Total-N concentrations in the $0-2 \mathrm{~cm}(\mathrm{~A})$ and $2-5 \mathrm{~cm}$ (B) strata - Control, Low Dose and High Dose areas. Bars define $95 \%$ confidence intervals.
Total-P concentrations presented evident variations linked to the fertilization process: Control area concentrations presented no modifications while fertilized areas presented a gradual increase in the concentrations, this increment being more accentuated in the HD areas for both strata (Fig. 8).

\section{$0-2 \mathrm{~cm} \mathrm{~A}$}
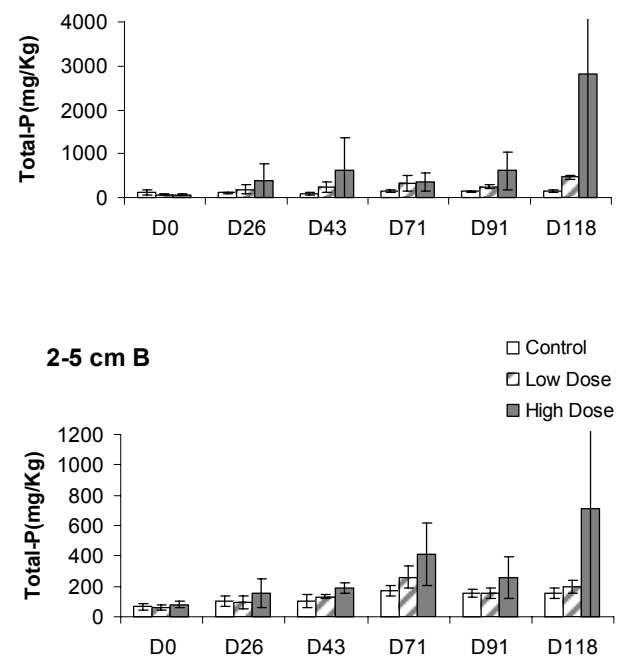

Fig. 8. Total-P concentrations in the $0-2 \mathrm{~cm}$ (A) and $2-5 \mathrm{~cm}$ (B) strata - Control, Low Dose and High Dose areas. Bars define $95 \%$ confidence intervals.

The Meiofauna consisted of 9 taxonomic groups: Nematoda, Copepoda (including Nauplii), Ostracoda, Kinorhyncha, Polychaeta, Oligochaeta, Foraminifera, Turbellaria and Acari. For statistical analysis, Turbellaria and Acari were treated together as "others" due to their low numbers and the Copepoda was separated from the Nauplii. Nematoda presented the highest density in all the samples as always representing more than $70 \%$ of meiofauna. Table 1 shows the density variations of each group for each treatment area during the study.

Meiofauna density presented a considerable decrease over the period of the experiment in the sampling areas HD and LD in both strata (Fig. 9). Despite the great differences in the meiofauna density as between the strata, this variable shows a pattern of variation similar for both strata throughout the experiment. Values of meiofauna density in the HD areas were almost 100 times lower in the final experiment as compared to Control or to HD Day 0 (Fig. 9). Meiofauna density in LD areas also showed a great reduction (of more than 10 times) in the final experiment (Fig. 9). 
Table 1. Mean values of meiofaunal groups density (ind. $/ 10 \mathrm{~cm}^{2}$ ) along the experiment period.

\begin{tabular}{ccccccccccccccccccccccccc}
\hline \hline Day & & 0 & & & 26 & & & 43 & & & 71 & & & 91 & \\
\hline & C & LD & HD & C & LD & HD & C & LD & HD & C & LD & HD & C & LD & HD & C & LD & HD \\
Nematoda & 4187 & 8830 & 5492 & 4872 & 4060 & 706 & 4044 & 4740 & 1941 & 3882 & 2402 & 176 & 3090 & 611 & 79.7 & 5726 & 567 & 59.1 \\
Copepoda & 695 & 221 & 534 & 198 & 153 & 61.8 & 52.0 & 49.3 & 29.3 & 22.2 & 40.1 & 13.6 & 7.0 & 0.5 & 1.6 & 96.5 & 27.6 & 7.6 \\
Ostracoda & 328 & 356 & 369 & 676 & 151 & 109 & 787 & 144 & 44.4 & 285 & 74.8 & 42.3 & 541 & 11.9 & 10.3 & 504 & 21.7 & 2.7 \\
Kinorhyncha & 188 & 306 & 198 & 332 & 73.2 & 54.2 & 90.0 & 10.3 & 3.3 & 398 & 15.2 & 22.8 & 152 & 0.0 & 2.2 & 259 & 3.8 & 2.2 \\
Polychaeta & 51.5 & 139 & 81.3 & 59.6 & 9.8 & 5.4 & 73.7 & 23.8 & 16.3 & 77.5 & 11.9 & 5.4 & 105 & 3.8 & 2.2 & 98.6 & 19.0 & 0.0 \\
Oligochaeta & 3.8 & 54.2 & 18.4 & 15.7 & 22.2 & 4.3 & 24.9 & 9.2 & 17.9 & 34.1 & 127 & 0.0 & 28.2 & 0.0 & 0.0 & 37.9 & 12.5 & 0.0 \\
Foraminifera & 21.7 & 34.7 & 39.6 & 48.8 & 8.1 & 12.5 & 17.3 & 4.9 & 8.7 & 16.8 & 6.5 & 1.1 & 16.8 & 0.0 & 1.6 & 22.2 & 1.1 & 0.0 \\
Nauplii & 65.0 & 71.5 & 145 & 80.8 & 137 & 47.7 & 2.2 & 0.0 & 1.1 & 2.7 & 11.4 & 1.6 & 0.0 & 0.0 & 0.0 & 1.6 & 2.7 & 0.0 \\
Others & 23.3 & 28.2 & 19.5 & 17.3 & 2.2 & 2.2 & 0.0 & 0.0 & 1.1 & 23.3 & 0.5 & 0.0 & 0.0 & 0.0 & 0.0 & 21.1 & 2.2 & 0.0 \\
\hline
\end{tabular}

\section{$0-2 \mathrm{~cm} \mathrm{~A}$}

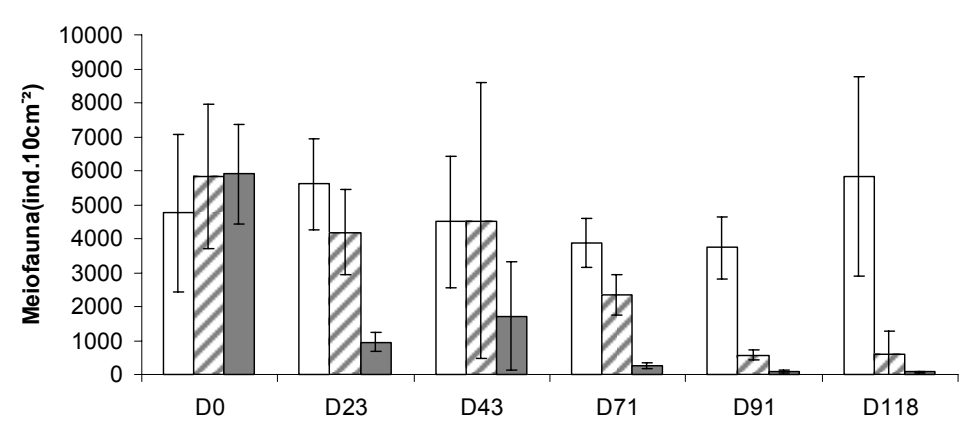

\section{$2-5 \mathrm{~cm} \mathrm{~B}$}

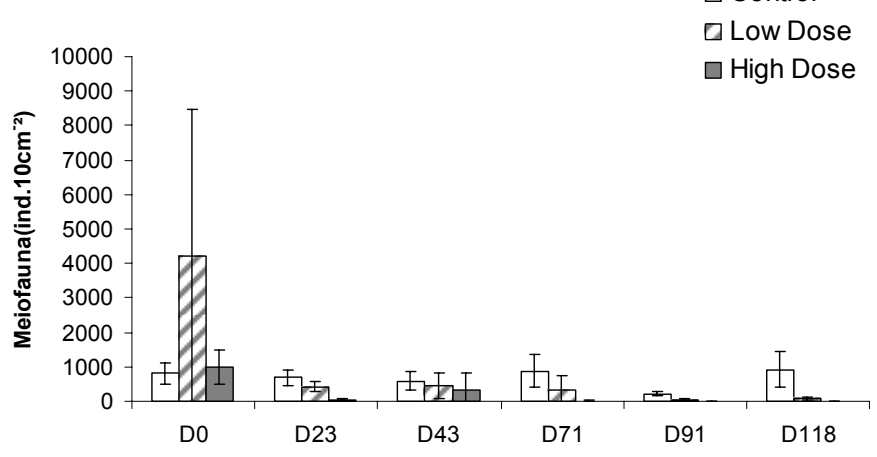

Fig. 9. Total Meiofauna densities in the $0-2 \mathrm{~cm}$ (A) and 2-5 cm (B) strata - Control, Low Dose and High Dose areas. Bars define $95 \%$ confidence intervals. 
However, the HD areas presented a faster decrease in the meiofauna densities than did the LD areas, with values which were already lower on Day 26 (Fig. 9).

In the HD areas all the meiofauna groups studied showed density decreases as early as Day 26 (Table 1). In the LD areas Nematoda and Copepoda did not show important variations as compared to Control until Day 71 but Ostracoda, Kinorhyncha, Polychaeta and Foraminifera presented reduced densities as from Day 26 (Table 1).

MDS ordination of densities (Figs 10A-C) showed a clear separation between samples from the $0-2 \mathrm{~cm}$ and $2-5 \mathrm{~cm}$ strata in all the areas of the experiment (C, LD and HD). Samples from the $0-2$ $\mathrm{cm}$ stratum were slightly grouped per day for treatments $\mathrm{C}$ and $\mathrm{LD}$; however, they differed greatly from their counterparts in the second stratum $(2-5 \mathrm{~cm})$. When the HD area was analyzed separately samples from the $0-2 \mathrm{~cm}$ stratum belonging to the end of experiment were observed mixed with samples from the $2-5 \mathrm{~cm}$ stratum belonging to the beginning of the experiment. Thus, the MDS did not present a clear distinction between the strata in the HD area (Fig. 10C).

ANOSIM analyses presented significant dissimilarities concerning sample distribution as between the strata and among the days in all areas (Table 2). Differences among days were particularly strong in both LD and HD areas as compared to Control (Table 2). BIOENV selected chlorophyll-a and phaeopigment concentrations as the factors that best structured the meiofauna community in the Control area $\left(\mathrm{r}_{\mathrm{S}}=0.631\right)$. Chlorophyll-a was the factor most closely associated with the biotic patterns in the $\mathrm{LD}$ areas; however, the correlation was very low $\left(\mathrm{r}_{\mathrm{s}}=\right.$ $0.059)$. Though with a low correlation $\left(\mathrm{r}_{\mathrm{S}}=0.222\right)$, phaeopigment concentration and redox potential (Eh) were the variables most closely associated with meiofauna variation in the HD areas.

Control A

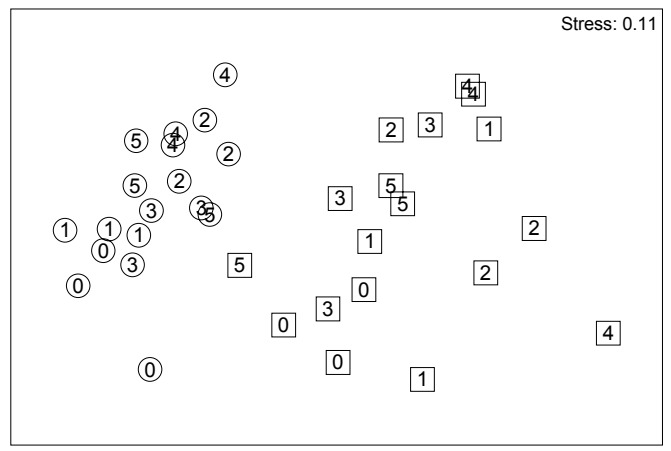

Low Dose B

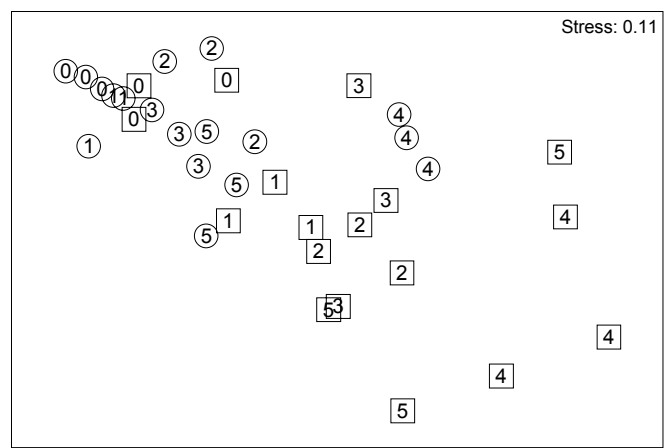

High Dose C

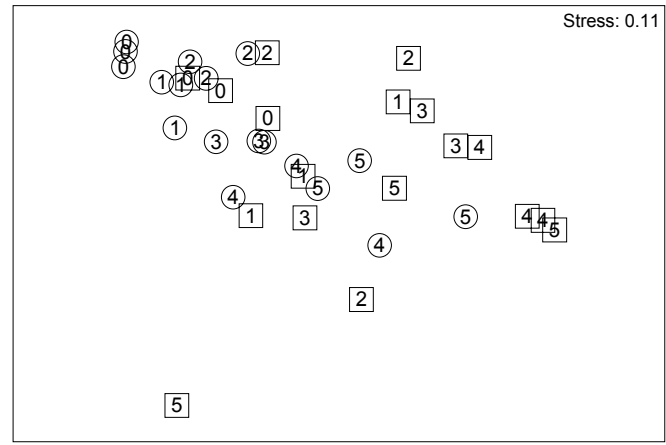

Fig. 10. Total Meiofauna MDS ordination in each area: Control (A), Low dose (B) and High Dose (C) during experiment $(0$ Day 0, 1 - Day 26, 2 - Day 43, 3 - Day 71, 4 - Day 91, 5 - Day 118) also showing the strata (0-2 cm - circle, 2-5 cm - square). 
Table 2. Two-way crossed ANOSIM results for differences among strata and days in the Control, Low Dose and High Dose areas.

\begin{tabular}{|c|c|c|c|c|c|c|}
\hline \multirow{3}{*}{ ANOSIM } & \multicolumn{6}{|c|}{ AREAS } \\
\hline & \multicolumn{2}{|c|}{ CONTROL } & \multicolumn{2}{|c|}{ LOW DOSE } & \multicolumn{2}{|c|}{ HIGH DOSE } \\
\hline & Global R & $\mathrm{p}$ & Global R & $\mathrm{p}$ & Global R & $\mathrm{P}$ \\
\hline $\begin{array}{c}\text { Strata } \\
(0-2 \mathrm{~cm} \times 2-5 \mathrm{~cm})\end{array}$ & 0.877 & 0.001 & 0.722 & 0.001 & 0.682 & 0.001 \\
\hline $\begin{array}{c}\text { Days } \\
(0 \times 26 \times 43 \times 71 \times 91 \times 118)\end{array}$ & 0.354 & 0.001 & 0.644 & 0.001 & 0.577 & 0.001 \\
\hline
\end{tabular}

Differences among the Control, High Dose and Low Dose areas were observed in the MDS density ordinations performed separately for the $0-2$ $\mathrm{cm}$ and $2-5 \mathrm{~cm}$ strata and total $(0-5 \mathrm{~cm})$ meiofauna (Fig. 11). ANOSIM confirmed these differences as among areas and sampling days (Table 3). Global $\mathrm{R}$ values for total meiofauna and the $2-5 \mathrm{~cm}$ stratum were lower than those obtained for the $0-2 \mathrm{~cm}$ stratum (Table 3). This can be seen in the MDS ordination where treatment samples are more clearly separated from each other in the $0-2 \mathrm{~cm}$ stratum but seem to be mixed, especially as regards the LD and HD samples, in the $2-5 \mathrm{~cm}$ stratum and total meiofauna (Fig. 11).

$0-2 \mathrm{~cm} \mathrm{~A}$

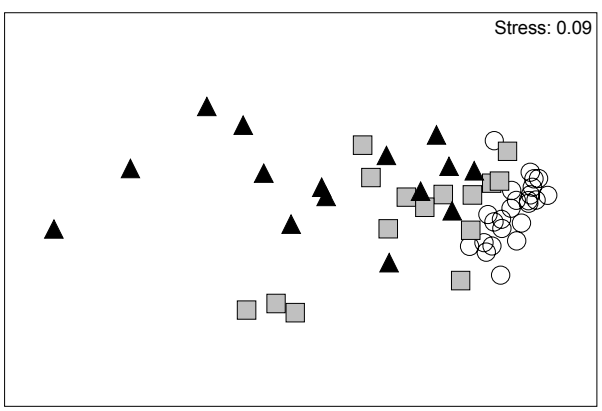

$2-5 \mathrm{~cm} \quad \mathrm{~B}$

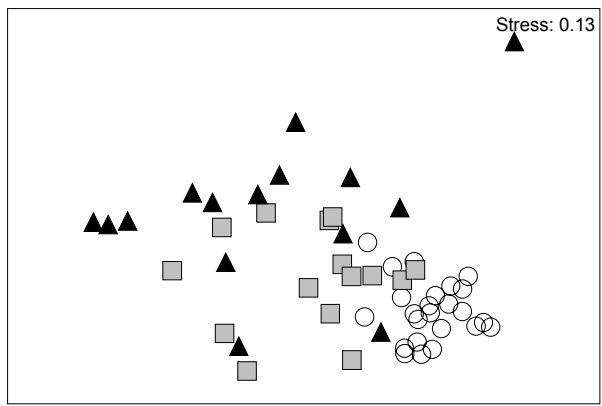

$0-5 \mathrm{~cm} \mathrm{C}$

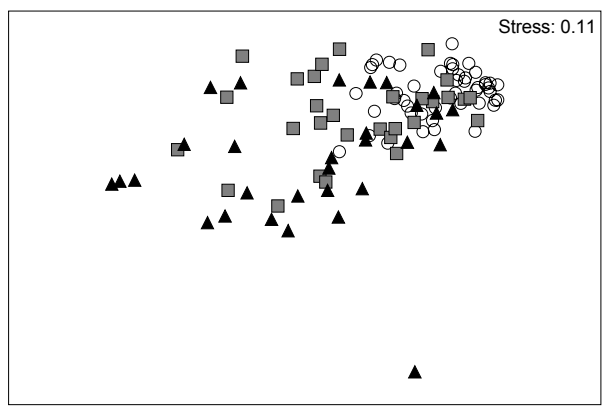

Fig. 11. Strata MDS ordination, 0-2 cm (A) and 2-5 cm (B) and 0-5 cm (C) according to Control (circle), Low Dose (gray square) and High Dose (black triangle) areas. 
Table 3. Two-way crossed ANOSIM results for differences among areas and days in the strata $(0-2 \mathrm{~cm}$ and $2-5 \mathrm{~cm})$ and total meiofauna.

\begin{tabular}{|c|c|c|c|c|c|c|}
\hline \multirow{3}{*}{ ANOSIM } & \multicolumn{6}{|c|}{ AREAS } \\
\hline & \multicolumn{2}{|c|}{$0-2 \mathrm{~cm}$} & \multicolumn{2}{|c|}{$2-5 \mathrm{~cm}$} & \multicolumn{2}{|c|}{ TOTAL } \\
\hline & $\mathrm{R}$ & $\mathrm{p}$ & $\mathrm{R}$ & $\mathrm{p}$ & $\mathrm{R}$ & $\mathrm{p}$ \\
\hline Areas & & & & & & \\
\hline (Control x Low Dose X High Dose) & 0.722 & 0.001 & 0.522 & 0.001 & 0.242 & 0.001 \\
\hline $\begin{array}{c}\text { Days } \\
(0 \times 26 \times 43 \times 71 \times 91 \times 118)\end{array}$ & 0.586 & 0.001 & 0.274 & 0.003 & 0.197 & 0.001 \\
\hline
\end{tabular}

BIOENV selected chlorophyll-a, phaeopigment and total-P concentrations $\left(r_{S}=0.497\right)$ as the environmental factors which best explain the meiofauna variation in the $0-2 \mathrm{~cm}$ stratum. Phosphorous concentration and redox potential were selected by the BIOENV as the environmental parameters which best explained the community structure in the $2-5 \mathrm{~cm}$ stratum $\left(\mathrm{r}_{\mathrm{S}}=0.446\right)$ while chlorophyll-a and redox potential $\left(\mathrm{r}_{\mathrm{s}}=0.277\right)$ were selected as the variables which best explain the total meiofauna structure.

\section{Discussion}

Eutrophication may be defined as water nutrient enrichment, especially by nitrogen and/or phosphorous and organic matter, leading to an increase in algae and superior plants, so as to cause a disturbance in the structure, function and stability of organisms present in the water and the quality of the water itself (ANDERSEN et al. 2006). Nutritional enrichment experiments are, therefore, fundamental for eutrophication studies, to evaluate the effect of eutrophication on the vegetal community and the consequent animal community response.

The sediment surface coloration changes in the areas during the experiment and sediment examination in the laboratory indicate a great increase in the incidence of filamentous cyanobacteria (Microcoleus chthonoplastes and Lyngbya aff. majuscula) in the fertilized areas, whereas in the Control area diatoms predominate (ML BotterCarvalho, unpublished data). However, differences in chlorophyll-a among the areas were small. Several non-exclusive hypotheses may be listed to explain this unusual (but see POSEY et al., 1995) result. On one hand, the filamentous cyanobacteria observed in the enriched area formed dense tangles in the sediment surface which may have made sediment samplings within dense plots difficult, especially taking into account the very small corer used for the microphytobenthos samplings: a $1.13 \mathrm{~cm}^{2}(1.2 \times 5 \mathrm{~cm})$ plastic syringe. On the other hand, microphytobenthos is known to present strong temporal and spatial variation in composition and biomass, forming evident patches on the sediment surface (AZOVSKY et al., 2004; JANOUSEK et al., 2007; SANDULLI; PINCKNEY, 1999). The chlorophyll-a concentration may show significant differences among areas with and without patches (SANTOS et al., 1995; JANOUSEK et al., 2007). Great variations, both temporal and spatial, probably determine the need for more replication to better discriminate among the control and treatment areas. A similar situation was observed by Posey et al. (1995) who were unable to discriminate among enrichment and control treatments. Finally, a similar process observed by Nilsson et al. (1991) may have occurred: they suggested that bubbles entrapped in the mucous rich top sediment layer in the enriching treatment may have lifted flakes from the producing layer thereby reducing the autotrophic biomass on their last experimental day (Day 28). Bubbles were also seen in the HD treatment plots as from Day 26 in our experiment.

Lyngbya aff. majuscula grows as microscopic filaments adhering to other fibers, stones and macroalgae, thus forming a "carpet" covering sediments (GARCIA; JOHNSTONE, 2006). The density increase observed for Lyngbya aff. majuscula is related to water and marine sediment oxygen depletion that promotes negative ecological effects and affects the meiofauna (DENISSON et al. 1999; GARCIA; JOHNSTONE, 2006).

The growing increase in total-P concentration in the fertilized areas over the period of the experiment and the absence of differences in the total-N concentration during the experiment in the same areas suggest nitrogen as a factor which limits algal growth in the environment studied (the higher solubility of nitrogen under field conditions cannot be disregarded). It is not surprising, therefore, as has already been registered by Watkinson et al. (2005), to find the proliferation of a nitrogen-fixing organism under potentially N-limiting conditions. 
The percentage of organic matter did not present any clear alterations over time in any of the experimental areas ( $\mathrm{C}, \mathrm{LD}$ and $\mathrm{HD})$. Organic matter results may be related to those observed for microphytobenthos distribution seeing that these factors are generally closely correlated. Furthermore, the significant reduction observed for the numbers of meiofauna (in the present study) and macrofauna (BOTTER-CARVALHO, 2007) may preclude the observation of increases in organic matter due to microphytobenthic development. Garcia and Johnstone (2006) observed that during Lyngbya majuscula blooms in Australia the benthic fauna presented a significant reduction in density and suggested that the increase or maintenance of sedimentary total nitrogen was the result of Lyngbya biomass increases.

Eh values presented an accentuated decrease in the HD area though not apparently related to organic matter. The increase in the sediment reduced conditions seems not, therefore, to be related to any increase in organic matter degradation (by oxygen demand), but rather to be due to a lack of oxygen (reduction conditions). A reduction in oxygen concentrations below L. majuscula mats has already been suggested by Garcia and Johnstone (2006). Moreover, variations of the redox potential were observed by Bolam et al. (2000) for macroalgae deposition on the sediment. Watkinson et al. (2005) suggested that sediments may play a critical role in the proliferation and persistence of $L$. majuscula blooms, through the provision of both phosphorus and iron under the reducing conditions created during the night, once a threshold biomass of L. majuscula has been attained, thus creating an environment conducive to $L$. majuscula's own survival. Data obtained from another Pernambuco estuary (Pina Basin, Capibaribe estuarine complex) using a gradient sampling design during an expanding spatial development of a cyanobacteria mat clearly indicated a significant negative correlation $(r=-$ $0.918 \mathrm{p}<0.05)$ between chlorophyll-a and redox potential (APMC Valença and PJP Santos, unpublished data).

In environments with organic pollution, the abundance of major meiofauna groups presents an increase in some studies but a decrease in others (COULL; CHANDLER, 1992). An increase in meiofauna abundance has already been qualitatively related to organic input (SCHRATZBERGER et al., 2000; DALTO et al., 2006) and to sediment redox potential (LAMPADARIOU et al., 2005). Widbom and Elmgren (1988) observed that only some meiofauna groups presented a positive response to an increase in organic input. On the other hand, according to Heip (1995), oxygen may be a limiting factor for infauna occupation in eutrophicated sediments; sediment enrichment may, therefore, lead to anoxic conditions and consequent elimination of fauna. Sediment enrichment has already been related to density decreases of total meiofauna and Nematoda in several studies (MOODLEY et al. 1998; LA ROSA et al. 2001; SANDULLI; NICOLA-GIUDICI, 1990; GEE et al. 1985; FRASCHETTI et al. 2006; SUTHERLAND et al. 2007). Recently, meiofauna and Nematoda densities have been negatively related to decreases in oxygen (TEIWES et al. 2007; HUA et al. 2006).

Meiofauna densities might increase during initial organic enrichment (GRAY, 1992). In the present study, meiofauna densities presented strong reductions in fertilized areas as from Day 26 (at the beginning of the experiment), especially in HD areas. Such results may be related either to the high nutrient input from each application, possibly associated with the already eutrophicated natural conditions in mangrove swamps that may magnify the nutrient input, or to the time scale used. Meiofauna organisms are known to have generation times on scales of from several days to a few weeks (HEIP et al., 1982; HICKS; COULL, 1983; SANTOS et al 1995; SOUZA-SANTOS et al., 1999), even in temperate areas. The interval between the initial nutrient input and the first sampling was long enough for two or more generations to have developed and thus for the sampling to have missed the initial density increase.

MDS and ANOSIM analyses indicated differences as between the strata and among the days; this pattern was expected for the structural variation in the meiofauna assemblage. Though weaker, the Control area also presented variations during the period of the experiment. Such differences are possibly to be related to variations in the Copepoda group and/or in the natural variability between the strata. Generally, studies point to the sediment depth as an important factor in infauna abundance. Moodley et al. (1998), while studying oxygen consumption by benthic infauna, and Sutherland et al. (2007), studying organic enrichment in the sediment, detected the highest benthic densities in the superficial layers. De Jesus-Navarrete and Herrera-Gomez (2002) found the highest Nematoda densities in the $0-2 \mathrm{~cm}$ stratum. Meiofauna density variations in the experimental areas were clearly related to chemical alterations in the environment, led by the microphytobenthic changes previously mentioned. The rapid meiofauna decrease corresponded to the extreme reduced conditions in the sediment determined by the experimental process in the HD and LD areas. Samples presented higher dissimilarity among days in the LD areas - a fact related to the gradual decrease in meiofauna density while dissimilarity among samples in the HD area was lower than that in the LD areas. This result is due to the sudden decrease in meiofauna density at the first 
sampling in the HD area after fertilization. Nevertheless, impaired species-specific feeding relationships (BUFFAN-DUBAU et al., 1996; DAHMS et al. 2007; DE TROCH et al., 2005; WICKMANS et al., 2007), due to the rapid modification of the autotrophic community, cannot be precluded. This last hypothesis would also explain the different time response of the various meiofauna groups.

Sediment redox potential was selected by BIOENV as one of the factors structuring the meiofauna of the HD treatment. As has previously been mentioned, an increase in reduced conditions does not seem to be related to the increase in the degradation of organic matter but to result rather from oxygen depletion due to the formation of cyanobacteria mats, a result similar to that found by Garcia and Jonhstone (2006), Bolam et al. (2000) and Watkinson et al. (2005). As in the HD area, Eh values limited the meiofauna assemblage structure in the 2-5 $\mathrm{cm}$ stratum. This stratum as a whole and HD samples presented the lowest meiofauna densities due to the low availability of oxygen, whether due to natural (2-5 $\mathrm{cm}$ stratum - Control area) or experimental (LD and HD) conditions. BIOENV indicated total-P as one of the factors that better explain the meiofauna assemblage structure in the $0-2 \mathrm{~cm}$ stratum. According to Watkinson et al. (2005) Lyngbya majuscula is phosphorus and iron limited and thus total-P may have had a variation pattern related to the bloom process and its consequences. In this study phosphorus functioned as a meiofauna assemblage modeler in the superficial stratum.

A reduction in oxygen availability in fertilized sediment may have been favored by the development of cyanobacteria mats and, consequently, modified the structure of the meiofauna assemblage, decreasing densities of all the groups during the experiment, with an immediate reduction in the second stratum $(2-5 \mathrm{~cm})$ related to the increase of reduced conditions followed by a decrease in density in the first stratum $(0-2 \mathrm{~cm})$.

\section{ACKNOWLEDGEMENTS}

The authors wish to express their thanks to the CNPq for the financial support n.477972/2004-7, for the research fellowship to PJP Santos n.305609/2004-1 and for the PhD scholarship awarded to M. L. Botter-Carvalho. A. B. Nascimento acknowledges a Facepe MSc scholarship. We are also grateful to MSc Priscila P. A. Murolo and an anonymous reviewer for helping with the English. Special thanks are due to two anonymous referees for their valuable comments and suggestions.

\section{REFERENCES}

ANDERSEN, J. H.; SCHLÜTER, L.; AERTEBJERG, G. Coastal eutrophication: recent developments in definitions and implications for monitoring strategies. $\mathbf{J}$. Plankt. Res., v. 28, n. 7, p 117-143, 2006.

AZOVSKY, A. .; CHERTOPROOD, E. S.; SABUROVA M. A.; POLIKARPOV, I. G. Spatio-temporal variability of micro- and meiobenthic communities in a White Sea intertidal sandflat. Estuar. coast. Shelf Sci., v. 60, p. 663-671, 2004

BOLAM, S. G.; FERNANDES, T. :; READ, P.; RAFFAELLI, D. Effects of macroalgal mats on intertidal sandflats: an experimental study. J. exp. mar. Biol. Ecol., v. 249, p. 123-137, 2000.

BOTTER-CARVALHO, M. L. Resposta da macrofauna bêntica estuarina a distúrbios: experimentos de eutrofização e recolonização no canal de Santa Cruz PE. 2007. 198pp. Tese (doutorado em oceanografia) Universidade Federal de Pernambuco, 2007.

BUFFAN-DUBAU, E.; WIT, R.; CASTEL, J. Feeding selectivity of the harpacticoid copepod Canuella perplexa in benthic muddy environments demonstrated by HPLC analyses of chlorin and carotenoid pigments. Mar. Ecol. Prog. Ser., v. 137, p. 71-82, 1996.

CLARKE, K. R. Non-parametric multivariate analyses of changes in community structure. Aust. J. Ecol., v. 18, p. 117-143. 1993.

CLARKE, K. R.; AINSWORTH, M. A method of linking multivariate community structure to environmental variables. Mar. Ecol. Prog. Ser., v. 92, p. 205-219, 1993.

CLARKE, K. R.; WARWICK, R. M. Changes in marine communities: an approach to statistical analysis and interpretation. Plymouth: NERC, 1994. $187 \mathrm{p}$.

COLIJN, F.; DIJKEMA, K. S. Species composition of benthic diatoms and distribution of chlorophyll-a on an intertidal flat in Dutch Waaden Sea. J. exp. mar. Biol. Ecol., v. 303, p. 157-171, 1981.

COULL, B. C.; CHANDLER G. T. Pollution and meiofauna - field, laboratory, and mesocosm studies. Oceanogr. mar. Biol., v. 30, p. 191-271, 1992.

COULL, B. C. Role of meiofauna in estuarine soft-bottom habitats. Austr. J. Ecol., v. 24, p. 327-343, 1999.

CPRH (Agência Estadual de Meio Ambiente e Recursos Hídricos). Diagnóstico sócio-ambiental do litoral norte. Recife, PE, 2001. $254 \mathrm{p}$.

DAHMS, H. U.; HARDER, T.; QIAN, P. Y. Selective attraction and reproductive performance of a harpacticoid copepod in a response to biofilms. J. exp. mar. Biol. Ecol., v. 341, p. 228-238, 2007.

DALTO, A. G.; GRÉMARE, A.; DINET, A.; FICHET, D. Muddy-bottom meiofauna responses to metal concentrations and organic enrichment in New Caledonia South-West Lagoon. Estuar. Coast. Shelf Sci., v. 67, p. 629-644, 2006.

DE JESUS NAVARRETE, A.; HERRERA-GOMEZ, J. Vertical distribution and feeding types of nematodes from Chetumal Bay, Quintana Roo, Mexico. Estuaries, v. 25 , p. 1131- 1137, 2002. 
DE TROCH, M.; STEINARSDÓTTIR, M. B. CHEPURNOV, V.; ÓLAFSSON, E. Grazing on diatoms by harpacticoid copepods: species-specific densitydependent uptake andmicrobial gardening. Aquat. Microb. Ecol., v. 39, p. 135-144, 2005.

DENISSON, W. C.; O'NEIL, J. M.; DUFFY, E.J.; OLIVER, P.E.; SHAW, G. . Blooms of the cyanobacterium Lyngbya majuscula in coastal waters of Queensland, Australia. Bull. Inst. océanogr. Monaco., v. 19, p. 501506, 1999.

EMBRAPA (Empresa Brasileira de Pesquisa Agropecuária). Manual de Métodos de Análise de Solo. 2 ed. Rio de Janeiro, 1997. $212 \mathrm{p}$.

FRASCHETTI, S.; GAMBI, C.; GIANGRANDE, A.; MUSCO, L.; TERLIZZI, A. ; DANOVARO, R. Structural and functional response of meiofauna rocky assemblages to Sewage pollution. Mar. Pollut. Bull., v. 52 , p. $540-548,2006$.

GARCIA, R.; JOHNSTONE, R. W. Effects of Lyngbya majuscula (Cyanophycea) blooms on sediment nutrients and meiofaunal assemblages in seagrass beds in Moreton Bay, Austrália. Mar. Freshw. Res., v. 57, p. 155-165, 2006.

GEE, J. M.; WARWICK, R. M.; SCHAANNING, M.; BERGE J. A.; AMBROSE, W. G. R. Effects of organic enrichment on meiofaunal abundance and community structure in sublittoral soft sediments. J. exp. mar. Biol. Ecol., v. 91, n. 3, p. 247-262, 1985.

GIERE, O. Meiobenthology: the microscopic fauna in aquatic sediments. Berlin: Springer-Verlag, 1993. 328 p.

GRAY, J.S. Eutrophication in the sea. In: COLUMBO, G.; FERRARI, I.; CECCHERELLI, V. U.; ROSSI, R. (Ed.) Marine eutrophication and population dynamics. Fredensborg: Olsen \& Olsen, 1992, p 3-15.

GRAY, J. S.; WU, R. S. S. ; OR, Y.Y. Effects of hypoxia and organic enrichment on the coastal marine environment. Mar. Ecol. Prog. Ser., v. 238, p. 249-279, 2002.

GUNKEL, G.; KOSMOL, J.; SOBRAL, M.; ROHN, H.; MONTENEGRO, S.; AURELIANO, J. Sugar cane industry as a source of water pollution - Case study on the situation in Ipojuca River, Pernambuco, Brazil. Water Air Soil Pollut., v. 180, p. 261-269, 2006.

HEIP, C. Eutrophication and zoobenthos dynamics. Ophelia, 1995, v. 41, p. 113- 136.

HEIP, C.; VINCX, M.; SMOL, N.; VRANKEN, G. The systematic and ecology of free-living marine nematodes. Helmintholog. Abstracts, v. 51, p. 1-24, 1982.

HICKS, G. R. F.; COULL, B. C. The ecology of marine meiobenthic harpacticoid copepods. Oceanogr. mar. Biol. a. Rev., v. 21, p. 67-175, 1983.

HIGGINS, R.P. \& THIEL, H. Introduction to the study of Meiofauna. Washington, DC: Smithsonian Press, 1988. $388 \mathrm{p}$.

HUA, E.; ZHANG, ZN. ; ZHANG, Y. Meiofauna distributions at the oxygen minimum zone in Changjiang (Yangtze) River Estuary Waters. Acta Oceanol. Sin., v. 25, p. 120-134, 2006.

JANOUSEK, C.N.; CURRIN, C.A. \& LEVIN, L.A. Succession of Microphytobenthos in a Restored Coastal Wetland. Estuar. Coasts, v. 30, n. 2, p. 265-276, 2007.
KENNEDY, A.D. \& JACOBY, C.A. Biological indicators of marine environmental health: Meiofauna - A neglected Benthic Component? Environ. Monit. Assessement, v. 54, n. 1, p. 47-68, 1999.

LA ROSA, T.; MIRTO, S.; MAZZOLA, A.; DANOVARO, R. Differential responses of benthic microbes and meiofauna to fish-farm disturbance in coastal sediments. Environ. Pollut., v. 112, p. 427-432, 2001.

LACERDA, L. D.; MOLISANI, M. M.; SENA, D.; MAIA, L. P. Estimating the importance of natural and anthropogenic sources on $\mathrm{N}$ and $\mathrm{P}$ emission to estuaries along the Ceará State Coast NE Brazil. Environ. Monit. Assessement., v. 141, p. 149-164, 2008.

LAMPADARIOU N.; KARAKASSIS, I.; TERASCHKE S.; ARLT G. Changes in benthic meiofaunal assemblages in the vicinity of fish farms in the Eastern Mediterranean. Vie Milieu, v. 55, n. 2, p. 61-69, 2005.

LORENZEN, C. J. Determination of chlorophyll and phaeopigments: Spectrophotometric Equations. Limnol. Ocean., v. 12, p. 343-346, 1967.

MARE, M. F. A study of marine benthic community with special reference to the micro-organisms. J. mar. Biol. Assoc., U. K, v. 25, p. 517-554, 1942.

MOODLEY, L.; HEIP, C. H. R.; MIDDELBURG, J. J.; Benthic activity in sediments of the northwestern Adriatic Sea: sediment oxygen consumption, macro- and meiofauna dynamics. J. Sea Res., v. 40, p. 263-280, 1998.

NILSSON, P.; JONSSON, B.; SWANBERG, I. L., SUNDBACK, K. Response of a marine shallow-water sediment system to an increased load of inorganic nutrients. Mar. Ecol. Prog. Ser., v. 71, p. 275-290, 1991.

POSEY, M.; POWELL, C.; CAHOON, L. ; LINDQUIST, D. Top down vs. bottom up control of benthic community composition on an tidal flat. J. exp. mar. Biol. Ecol., v. 185, p. 19-31, 1995.

SANDULLI, R.; NICOLA-GIUDICI, M. Pollution effects on the structure of meiofaunal communities in the Bay of Naples. Mar. Pollut. Bull., v. 20, n. 5, p. 223-227, 1990.

SANDULLI, R.; PINCKNEY, J. Patch sizes and spatial patterns of meiobenthic copepods and benthic microalgae in sandy sediments: a microscale approach. J. Sea Res., v. 41, p. 179-187, 1999.

SANTOS P. J. P.; CASTEL, J.; SOUZA-SANTOS, L.P. Microphytobenthic patches and their influence on meiofaunal distribution. Cah. Biol. Mar., v. 36, p. 133139, 1995.

SCHRATZBERGER, M.; GEE, J. M.; REES, H. L.; BOYD, S. E.; WALL, C. M.. The structure and taxonomic composition of sublittoral meiofauna assemblages as an indicator of the status of marine environments. J.mar. Biol. Assoc., U.K., v. 80, p. 969-980, 2000.

SILVA, T.A.; NEUMANN-LEITÃO, S.; SCHWAMBORN, R.; GUSMÃO, L.M.O.; NASCIMENTO-VIEIRA, D.A. Diel and seasonal changes in the macrozooplankton community of a tropical estuary in Northeastern Brazil. Rev. Bras. Zool., v. 20, n. 3, p. 439-446, 2003.

SOUZA-SANTOS L. P.; SANTOS P. J. P.; CASTEL, J. Development and population dynamics of Amonardia normani Brady reared on axenic and non-axenic diatoms. J. exp. mar. Biol. Ecol., v. 235, p. 167-182, 1999. 
STEYAERT, M.; GARNER， N.; GANSBEKE， D. \& VINCX, M. Nematode communities from North Sea: environmental controls on species diversity and vertical distribution within the sediment. J. mar. Biol. Assoc., U. K., v. 76, p. 253-264, 1999.

SUTHERLAND, T. F.; LEVINGS C. D.; PETERSEN P. ; PIERCEY, B. The use of meiofauna as indicators of benthic organic enrichment associated with salmonid aquaculture. Mar. Pollut. Bull., v. 54, p. 1249-1261, 2007.

TEIWES, M; BERGTOLD, M. \& TRAUNSPURGER, W. Factors influencing the vertical distribution of nematodes in sediments. J. Freshw. Ecol., v. 22, p. 429- 439, 2007.

WATKINSON, A. J.; O’NEIL, J. M. ; DENNISONA, W.C. Ecophysiology of the marine cyanobacterium, Lyngbya majuscule (Oscillatoriaceae) in Moreton Bay, Australia. Harmf. Algae, v. 4, p. 697-715, 2005.
WETZEL, R. G.; LIKENS, G .E. Limnological analyses. 2 ed. New York: Springer Verlag, 1990. 338 p.

WICKMANS, M.; CHEPURNOV, V.A.; VANREUSEL, A. ; TROCH, M. Effects of food diversity on diatom selection by harpacticoid copepods. J. exp.Mar. Biol. Ecol., v. 345, p. 119-128, 2007.

WIDBOM, B.; ELMGREN, R. Response of benthic meiofauna to nutrient enrichment of experimental marine ecosystems.Mar. Ecol. Progr. Ser., v. 42, p. 257268,1988 .

(Manuscript received 26 February 2008; revised 18 June 2008; accepted 11 September 2008) 